\title{
Karakterisasi Senyawa Bioaktif Kapang Laut Trichoderma asperellum MT02 dengan Aktivitas Anti-Extended Spectrum $\beta$-Lactamase (ESBL) E. coli
}

\author{
Mada Triandala Sibero ${ }^{1,4}$, Aninditia Sabdaningsih'2, Ocky Karna Radjasa ${ }^{3}$, Agus $^{2}$ \\ Sabdono', Agus Trianto' dan Subagiyo'
}

\author{
'Departemen IImu Kelautan, Fakultas Perikanan dan Ilmu Kelautan, Universitas Diponegoro \\ 2Departemen Sumberdaya Akuatik, Fakultas Perikanan dan Ilmu Kelautan, Universitas Diponegoro \\ JI. Prof. H. Soedharto, SH, Tembalang, Semarang, Indonesia 50275 \\ 3Kementerian Riset, Teknologi, Dan Pendidikan Tinggi Republik Indonesia \\ Jl. M. H. Thamrin No. 8, Jakarta Pusat 10340 \\ 4 Marine Science Techno Park \\ JI. UNDIP, Desa Teluk Awur, Jepara, Jawa Tengah, 59427 \\ Email: madatriandala@hotmail.com
}

\begin{abstract}
Characterization of Bioactive Compound from Marine Fungi Trichoderma asperellum MT02 Exhibiting Anti-Extended Spectrum B-Lactamase (ESBL) E. coli
\end{abstract}

The Trichoderma asperellum MT02 has been reported to has antibacterial activity against the Extended Spectrum $\beta$-Lactamase (ESBL) E. coli based on the screening results through an agar plug method. This study aimed to evaluate the antibacterial activity of T. asperellum MTO2 and characterize the composition of the bioactive compounds group possessed in its crude extract. The isolate was cultured in the Malt Extract Broth (MEB) media (static, $27{ }^{\circ} \mathrm{C}, 15$ days). The intracellular metabolites from mycelium were extracted using methanol while extracellular metabolites from broth media were extracted using ethyl acetate. The antibacterial activity of crude extracts was tested using the paper disc diffusion method while bioactive compounds were characterized using the phytochemical method. The results showed that the antibacterial activity of the broth media extract performed a greater activity than the crude extract from the mycelium. The crude extract from mycelia only contained flavonoid and phenol hydroquinone compounds while the crude extract from broth media contains alkaloids, flavonoids, phenols hydroquinone and saponins.

Keywords: Antibacterial; bioactives; phytochemical; Trichoderma

\begin{abstract}
Abstrak
Kapang Trichoderma asperellum MT02 telah dilaporkan memiliki potensi sebagai penghasil senyawa antibakteri melawan Extended Spectrum $\beta$-Lactamase (ESBL) E. coli berdasarkan hasil penapisan melalui metode agar plug. Penelitian ini bertujuan untuk mengetahui aktivitas antibakteri ekstrak kasar kapang T. asperellum MTO2 serta komposisi golongan senyawa bioaktif yang dimiliki. Kapang dikultur pada media Malt Extract Broth (MEB) (statis, $27^{\circ} \mathrm{C}$, 15 hari) di mana metabolit intraseluler dari miselium diekstrak menggunakan metanol sedangkan metabolit ekstraseluler dari media kaldu diekstrak menggunakan etil asetat. Aktivitas antibakteri ekstrak kasar diuji menggunakan metode difusi kertas cakram sedangkan senyawa bioaktif dikarakterisasi menggunakan metode fitokimia. Hasil penelitian menunjukkan bahwa aktivitas antibakteri asal ekstrak media kaldu lebih baik dibandingkan ekstrak kasar asal miselium kapang. Ekstrak kasar kapang asal miselia hanya mengandung senyawa golongan flavonoid dan fenol hidrokuinon sedangkan ekstrak kasar asal media kaldu mengandung alkaloid, flavonoid, fenol hidroquinon dan saponin.
\end{abstract}

Kata Kunci: Antibakteri; bioaktif; fitokimia; Trichoderma 


\section{PENDAHULUAN}

Sumber daya laut diketahui sebagai penyedia bahan aktif yang dapat dimanfaatkan di bidang pangan fungsional, kosmeseutikal maupun farmasi (Suleria et al., 2015; Guillerme et al., 2017). Berbagai penelitian telah membuktikan spons asal laut Indonesia menghasilkan metabolit yang mampu menghambat pertumbuhan sel mikroba patogen, menghambat kinerja enzim tertentu yang tidak diinginkan hingga kandidat obat kanker yang potensial (Abdjul et al., 2017; Ibrahim dan Mohamed, 2017; Maarisit et al., 2017; Zubair et al., 2018). Namun, pengambilan biomassa suatu spesies spons tertentu secara terus menerus dikarenakan senyawa target bioaktif yang dihasilkan sangat sedikit diprediksikan akan menyebabkan ketidakseimbangan ekosistem laut hingga punahnya suatu spesies. Penelitian yang dilakukan oleh Ibrahim dan Mohamed (2017) hanya memperoleh 2,6 mg senyawa ingenine $\mathrm{E}$ yang sangat potensial sebagai antikanker dari 1,3 kg jaringan kering spons Acanthostrongylophora ingens. Penelitian serupa yang dilakukan oleh Ebada et al. (2017) hanya mampu mengisolasi 1,7 mg senyawa Nakijiquinone $G$ dari $130 \mathrm{gr}$ jaringan kering spons Dactylospongia elegans yang diperoleh dari Ambon. Rendahnya rendemen senyawa yang diperoleh serta tingginya kemungkinan kerusakan lingkungan yang dapat terjadi menyebabkan pergantian pemanfaatan sumber senyawa bioaktif dari spons menjadi mikroorganisme asosiasi spons, salah satunya adalah kapang.

Kapang merupakan anggota dari kingdom fungi yang berukuran mikroskopik, multi seluler dan memproduksi filamen. Kajian mengenai aktivitas biologis dari kapang laut asal spons diketahui memiliki aktivitas antibakteri yang sangat baik untuk dikembangkan sebagai antibiotik. Liu et al. (2018) berhasil mengisolasi senyawa penicillilactone A asal kapang Penicillium sp. LS54 yang merupakan kapang asosiasi spons Haliclona sp. Senyawa ini telah dianggap sebagai kandidat antibakteri yang sangat baik melawan patogen udang Vibrio harveyi dengan nilai MIC $8 \mu \mathrm{g} / \mathrm{mL}$. Aplikasi senyawa antibakteri asal kapang melawan bakteri patogen manusia telah dilakukan oleh
Fredimoses et al. (2018). Penelitian tersebut melaporkan bahwa senyawa emerixanthone E yang diproduksi oleh kapang Emericella sp. SCSIO 05240 mampu melawan bakteri patogen manusia, di antaranya Escherichia coli (ATCC 29922), Klebsiella pneumoniae (ATCC 13883), Staphylococcus aureus (ATCC 29213), Enterococcus faecalis (ATCC 29212), dan Acinetobacter baumannii (ATCC 19606).

Pencarian senyawa antibiotik baru menjadi sebuah topik penting bagi perkembangan ilmu kesehatan dikarenakan sulitnya penyembuhan infeksi bakteri yang sudah resisten terhadap beberapa gelongon antibiotik atau lebih dikenal dengan multidrugs resistant (MDR) bacteria. Center for Disease Control and Prevention (CDC) mengungkapkan bahwa bakteri MDR dari famili Enterobacteriaceae seperti Escherichia coli telah resisten terhadap antibiotik komersial turunan $\beta$-laktam seperti penicillins, cephalosporins, dan monobactam aztreonam yang dikenal dengan istilah extended spectrum $\beta$-lactamase (ESBL) di mana hal ini akan mempersulit penyembuhan pasien yang terinfeksi oleh bakteri ini (CDC, 2018). Bakteri ESBL E. coli dilaporkan sebagai patogen yang mengakibatkan diare pada beberapa kasus kesehatan di kota Surabaya (Wasito et al., 2017). Kitagawa et al. (2018) juga melaporkan bahwa bakteri ESBL E. coli merupakan patogen dominan yang menyebabkan infeksi saluran kemih (ISK) pada pasien di rumah sakit Dr. Soetomo, Surabaya. Bakteri ini juga diketahui sebagai penyebab infkesi lain seperti pneumonia, abses, sepsis hingga infeksi kulit dan tulang (Natalia et al., 2018). Bakteri ini sangat berbahaya karena mampu menyebar malalui vektor lain seperti makanan dari hewani yang berasal dari rumah potong yang telah terkontaminasi. Hasil penelitian Sudarwanto et al. (2017) pada rumah potong hewan di Bogor mendapatkan bahwa dari seluruh total bakteri yang diisolasi diketahui bahwa $14,3 \%$ diantaranya merupakan bakteri ESBL E. coli. Penelitian ini meneruskan kajian sebelumnya yang telah melaporkan potensi kapang laut fakultatif Trichoderma asperellum MTO2 asal spons Cinachyrella sp. yang menunjukkan potensi antibakteri melawan bakteri ESBL E. coli yang diisolasi dari pasien rumah sakit Dr. Kariadi Semarang 
(Sibero et al., 2017). Penelitian ini bertujuan untuk mengetahui aktivitas antibakteri ekstrak kasar kapang $T$. asperellum MTO2 serta komposisi golongan senyawa bioaktif yang terdapat di ekstrak kasar asal miselium dan media kaldu (broth).

\section{MATERI DAN METODE}

Kapang T. asperellum MT02 merupakan isolat koleksi dari Divisi Kapang Laut, Laboratorium Bioteknologi Laut Tropis, Fakultas Perikanan dan IImu Kelautan, Universitas Diponegoro. Kapang ini diisolasi dari spons Cinachyrella sp. asal perairan Pulau Panjang, Jepara (Sibero et al., 2017). Kapang diremajakan dari stok kultur menggunakan media Malt Extract Agar (MEA) dari HiMedia pada suhu ruangan $\left(27^{\circ} \mathrm{C}\right)$ selama 7 hari. Morfologi koloni kapang hasil peremajaan selanjutnya dibandingkan dengan foto morfologi stok, koloni yang memperlihatkan kemiripan yang sesuai sehingga isolat ini dilanjutkan untuk digunakan pada penelitian ini.

\section{Kultivasi kapang}

Sebanyak 4 potong dengan ukuran $1 \times 1 \mathrm{~cm}^{2}$ kapang $T$. asperellum MTO2 yang berusia 5 hari dari media MEA dipindahkan ke dalam media Malt Extract Broth (MEB) bervolume $100 \mathrm{~mL}$ dalam Erlenmeyer dengan tiga ulangan. Kapang dikultivasi dengan keadaan statis (stand culture) selama 15 hari pada suhu ruang $\left(27^{\circ} \mathrm{C}\right)$ (Sibero et al., 2018').

\section{Ekstraksi senyawa bioaktif}

Senyawa bioaktif diekstrak menggunakan metode ekstraksi tunggal, di mana setiap sumber diekstraksi hanya menggunakan satu jenis pelarut. Kapang yang telah dikultivasi selama 15 hari selanjutnya dipisahkan antara media kaldu (broth) dan miseliumnya menggunakan kertas saring. Miselium kapang yang diperoleh selanjutnya dikeringkan menggunakan desikator yang berisi gel silika selama $3 \times 24$ jam kemudian ditambahkan pelaurt methanol sebesar $100 \mathrm{~mL}$ dan diagitasi menggunakan shaker (120 r.p.m.; 24 jam). Selanjutnya miselia dan pelarut dipisahkan menggunakan kertas saring.
Pelarut dipekatkan menggunakan rotary evaporator pada suhu 30-35 `C. Ekstraksi senyawa bioaktif dari media kaldu dilakukan dengan penambahan pelarut etil asetat dengan rasio 3:1 (pelarut:media kaldu) kemudian diagitasi menggunakan shaker (120 r.p.m.; 24 jam). Media kaldu dan pelarut dipisahkan menggunakan corong pisah (separatory funnel), selanjutnya fase pelarut dipekatkan menggunakan rotary evaporator (Eyela) pada suhu 30-33 ${ }^{\circ} \mathrm{C}$. Ekstrak kasar yang diperoleh selanjutnya dikeringkan menggunakan gas nitrogen dan ditimbang untuk mendapatkan bobotnya. Ekstrak selanjutnya disimpan menggunakan pelapis aluminium foil pada suhu $-20{ }^{\circ} \mathrm{C}$ untuk menjaga kestabilan senyawa bioaktif dalam ekstrak kasar (Sibero et al. 2018')

\section{Uji aktivitas antibakteri}

Bakteri ESBL E. coli merupakan isolat klinis diisolasi dari pasien rumah sakit $\mathrm{Dr}$. Kariadi Semarang. Bakteri diremajakan pada media MacConkey (HiMedia) selama 24 jam sebelum digunakan dalam uji antibakteri. Tahap ini mengacu pada standar pengujian yang diberikan oleh CLSI (2016). Bakteri uji diencerkan menggunakan garam fisiologis hingga mencapai kekeruhan 0,5 McFarland selanjutnya diinokulasikan menggunakan cotton swab steril pada seluruh permukaan media Mueller Hinton Agar (MHA) (Merck). Sediaan ekstrak dibuat dengan cara melarutkan ekstrak kasar menggunakan dimethyl sulfoxide (DMSO) (Merck) menjadi konsentrasi $500 \mu \mathrm{g} / \mathrm{mL}, 350 \mu \mathrm{g} / \mathrm{mL}, 250 \mu \mathrm{g} / \mathrm{mL}$, $100 \mu \mathrm{g} / \mathrm{mL}$ dan $50 \mu \mathrm{g} / \mathrm{mL}$. Sebanyak $15 \mu \mathrm{L}$ dari setiap konsentrasi sediaan ekstrak diinjeksikan ke dalam kertas cakram berukuran $8 \mu \mathrm{m}$ (Advantec) kemudian dikering anginkan lalu diletakkan ke atas media MHA yang telah diinokulasikan bakteri uji, kertas cakram yang berisi antibiotik Amoxicillin $10 \mu \mathrm{g} /$ cakram (Oxoid) digunakan sebagai kontrol positif sedangkan DMSO tanpa ekstrak sebagai kontrol negatif. Tahapan ini dilakukan dengan empat pengulangan. Inkubasi dilakukan pada suhu $37^{\circ} \mathrm{C}$ selama 24 jam. Zona hambat yang terbentuk merupakan indikator keberadaan senyawa bioaktif sebagai antibakteri. Diameter zona hambat yang terbentuk selanjutnya diukur dengan jangka sorong untuk mengetahui efektivitas konsentrasi (Sibero et al. 20181,2). 


\section{Fitokimia}

Kandungan senyawa bioaktif pada ekstrak kasar kapang T. asperellum MTO2 dilakukan menggunakan metode fitokimia (Hidayat dan Nurjanah, 2016). Modifikasi yang dilakukan berupa ektrak dilarutkan dalam DMSO dan akuades (1:5) untuk uji.

\begin{abstract}
Alkaloid
Masing-masing sebanyak $300 \mu \mathrm{L}$ larutan ekstrak dimasukkan ke dalam sumur uji kemudian sebanyak 2 tetes $\mathrm{H}_{2} \mathrm{SO}_{4} \quad 2 \mathrm{~N}$ ditambahkan beserta reagen Dragendorff, Meyer dan Wagner. Hasil positif pada Dragendorff akan memberikan endapan berwarna jingga hingga merah, endapan putih kekuningan pada reagen Meyer dan endapan cokelat untuk reagen Wagner.
\end{abstract}

\section{Flavonoid}

Sebanyak $0.1 \mathrm{mg}$ bubuk Magnesium (Mg), $350 \mu \mathrm{L}$ amil alkohol (dibuat dengan cara menambahkan $\mathrm{HCl} 37 \%$ dan etanol $95 \%$ dengan perbandingan 1:1), dan $350 \mu \mathrm{L}$ alkholol kedalam sumur uji yang berisi $300 \mu \mathrm{L}$ larutan sampel. Hasil positif diperlihatkan dengan munculnya warna merah, kuning maupun jingga pada lapisan amil alkohol.

\section{Fenol hidrokuinon}

Larutan ekstrak ditambahkan 2 tetes larutan $\mathrm{FeCl}_{3} 5 \%$, perubahan warna menjadi hijau menandakan keberadaan senyawa fenol pada ekstrak kapang.

\section{Saponin}

Sebanyak $1 \mathrm{mg}$ ektrak kasar ditambahkan ke dalam $5 \mathrm{~mL}$ akuades selanjutnya dipanaskan dan diaditasi secara vertikal. Munculnya busa yang stabil selama 30 menit menunjukkan hasil positif pada uji ini.

\section{Steroid/Terpenoid}

Sebanyak $1 \mathrm{mg}$ ekstrak kasar dilarutkan dalam $1 \mathrm{~mL}$ kloroform, kemudian ditambhkan 5 tetes asetat anhidrat dan 3 tetes $\mathrm{H}_{2} \mathrm{SO}_{4}$ pekat. Munculnya warna merah dan berubah menjadi biru dan hijau menunjukkan hasil positif pada uji ini.

Seluruh data diolah menggunakan perangkat lunak SPPS Statistic 21. Pengaruh konsentrasi ekstrak kasar kapang terhadap aktivitas antibakteri melawan ESBL E. coli diolah menggunakan rancangan acak tunggal dengan selang kepercayaan 95\% ( $P$ $<0,05)$. Uji lanjut yang digunakan adalah Duncan test.

\section{HASIL DAN PEMBAHASAN}

Kapang laut merupakan kapang yang diduga berasal dari lingkungan darat maupun perairan tawar yang terbawa ke lingkungan laut, namun kapang ini tidak dapat tumbuh dan berkembang pada lingkungan laut yang bersalinitas. Salah satu kapang laut yang berhasil diisolasi dari penelitian sebelumnya adalah $T$. asperellum MT02 (Sibero et al., 2017). Kapang ini menjadi koleksi isolat yang dipreservasi menggunakan air steril selama 3 bulan pada suhu $4{ }^{\circ} \mathrm{C}$. Penumbuhan isolat ini pada media Malt Extract Agar (MEA) selama 7 hari memperlihatkan bahwa morfologi koloni kapang hasil penumbuhan kembali memiliki kesamaan identik dengan morfologi koloni kapang sebelum dipreservasi (Sibero et al., 2017). Kapang ini memiliki karakteristik khas koloni berupa adanya pola pertumbuhan radial hijau tua dan hijau muda (Gambar 1). Stocco et al. (2010) melaporkan bahwa kapang yang dipreservasi menggunakan air steril dapat menyimpan isolat Trichoderma hingga umur 12-18 bulan. Selama masa penyimpanan, air akan menjaga bentuk sel konidia kapang dan tidak memicu pertumbuhan konidia menjadi miselium sehingga konidia tidak kering dan mati (Bhai dan Anandaraj, 2014).

Metode preservasi mennggunakan air steril banyak dilakukan untuk spesies kapang dari genus Trichoderma (Stocco et al., 2010; Bhai dan Anandaraj, 2014; lqbal et al., 2017). Kapang T. asperellum MTO2 selanjutnya dikultivasi pada media kaldu (broth) dengan tujuan produksi senyawa antibakteri. Senyawa antibakteri dari isolat $T$. asperellum MT02 diekstrak dari miselium menggunakan metanol dan media kaldu menggunakan etil asetat. Jumlah rendemen ekstrak dari kedua sumber (Tabel 1). Berdasarkan hasil pengukuran jumlah ekstrak kasar diketahui bahwa miselium yang diekstrak menggunakan metanol menghasilkan rendemen yang lebih banyak $(7,5309 \pm 3,1305$ $\mathrm{b} / \mathrm{b} \%$ ) dibandingkan dengan ekstrak kasar yang dihasilkan oleh media kaldu 
$(0,0191 \pm 0,0078 \mathrm{~b} / \mathrm{v} \%)$. Jumlah rendemen dipengaruhi oleh jumlah senyawa yang dapat diekstrak oleh pelarut organik yang digunakan, etil asetat akan mengekstrak senyawa yang bersifat semi-polar sedangkan metanol akan mengekstrak senyawa polar, sedikit semi-polar dan senyawa non-polar.

Tujuan mengekstraksi miselium dan media kaldu (broth) secara terpisah adalah untuk mengevaluasi aktivitas antibakteri serta mengkarakterisasi golongan senyawa bioaktif yang terkandung pada metabolit yang diproduksi sencara intraselular dan ekstraselular. Metabolit intraselular adalah metabolit yang dihasilkan dan disimpan di dalam sel sehingga ekstraksi yang dilakukan bertujuan untuk menarik metabolit agar berpindah dari dalam sel menuju pelarut organik yang digunakan; sedangkan metabolit ekstraselular adalah metabolit yang dihasilkan oleh sel kemudian disekresikan ke lingkungan (luar sel) sehingga ekstraksi yang dilakukan bertujuan untuk memindahkan metabolit dari media kultur ke pelarut organik. Penelitian ini menggunakan pelarut etil asetat untuk mengekstrak senyawa metabolit ekstraselular, hal ini didasari kepolaran etil asetat $(4,4)$ lebih rendah dibandingkan media kaldu yang terbuat dari air $(9,0)$ dan nilai kelarutan yang rendah di dalam air $(8,7 \%)$ sehingga selama proses ekstraksi akan terbentuk dua fase organik yang terpisah dan memudahkan peneliti untuk melakukan melakukan pemekatan metabolit yang diekstrak (Sadek, 2002). Evaluasi kemampuan T. asperellum MT02 dalam menginhibisi pertumbuhan bakteri ESBL E. coli (Gambar 2).

Berdasarkan hasil pengukuran diameter zona hambat yang terbentuk maka diketahui bahwa ekstrak kasar yang berasal dari miselium memiliki kemampuan antibakteri yang lebih rendah dibandingkan kontrol positif Amoxicillin $10 \mu \mathrm{g} /$ cakram (11,83 $\pm 0,2$ $\mathrm{mm})$. Gambar 2 menunjukkan bahwa ekstrak pada konsentrasi 250 hingga $500 \mu \mathrm{g} / \mathrm{mL}$ memiliki diameter zona hambat yang tidak saling berbeda nyata. Hal ini berarti konsentrasi ekstrak kasar sebesar $250 \mathrm{\mu g} / \mathrm{mL}$ $(3,73 \pm 0,2 \mathrm{~mm})$ dan $350 \mu \mathrm{g} / \mathrm{mL}(3,73 \pm 0,2$ $\mathrm{mm})$ mampu menghambat pertumbuhan bakteri uji sama baiknya dengan konsentrasi ekstrak kasar sebesar $500 \mu \mathrm{g} / \mathrm{mL}(3,73 \pm 1,2$ $\mathrm{mm})$. Hal ini berbeda dengan aktivitas antibakteri ekstrak kasar asal media kaldu yang ditunjukkan oleh Gambar 2. Hasil uji

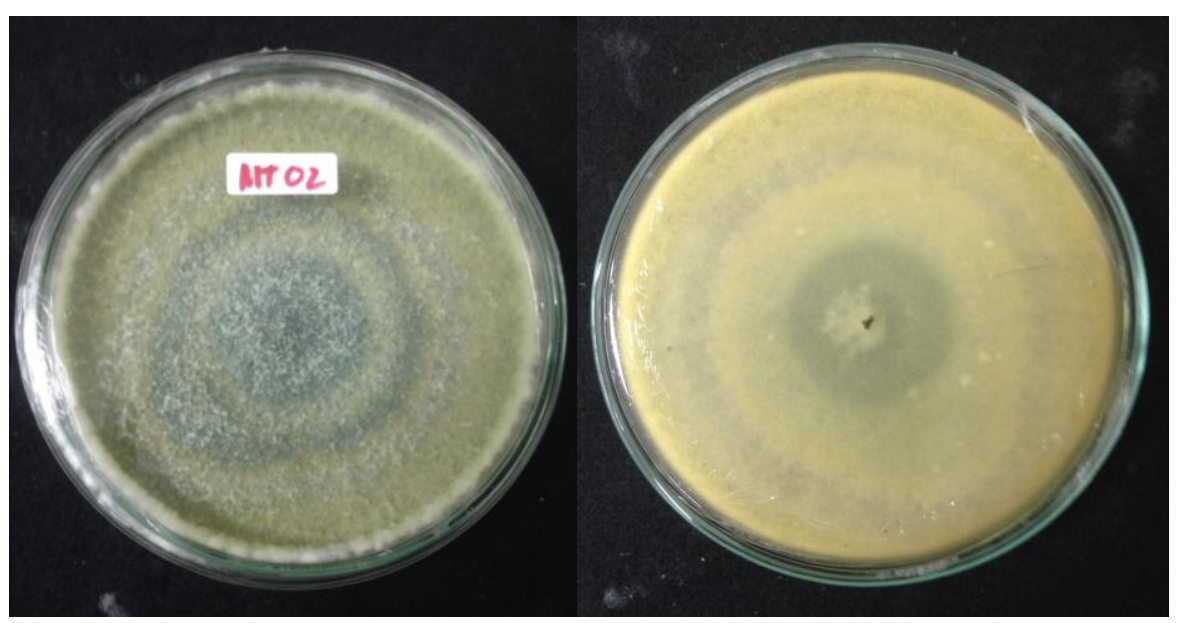

Gambar 1. Kloni kapang T. asperellum MT02 umur 7 hari pada media MEA

Tabel 1. Jumlah rendemen ekstrak kasar kapang T. asperellum MT02

\begin{tabular}{cc}
\hline Sumber & Bobot rendemen ekstrak kapang $(\%)$ \\
\hline Miselium & $7,5309 \pm 3,1305(\mathrm{~b} / \mathrm{b})$ \\
Media & $0,0191 \pm 0,0078(\mathrm{~b} / \mathrm{v})$ \\
\hline
\end{tabular}

(Rata-rata \pm standar deviasi; b/b: bobot/bobot; b/v: bobot/volum) 
statistik memperlihatkan konsentrasi ekstrak kasar berpengaruh nyata terhadap kemampuannya dalam menghambat pertumbuhan bakteri ESBL E. coli $(P<0,05)$.

Ekstrak dengan konsentrasi sebesar 350 $\mu \mathrm{g} / \mathrm{mL}(11,85 \pm 1,9 \mathrm{~mm})$ memiliki zona hambat yang tidak berbeda nyata dengan kontrol positif, lebih lagi pada konsentrasi $500 \mu \mathrm{g} / \mathrm{mL}$ $(13,90 \pm 0,6 \mathrm{~cm})$ diketahui bahwa ekstrak kapang dari media kaldu mampu menghambat bakteri ESBL E. coli lebih baik jika dibandingkan dengan kontrol positif Amoxicillin $10 \mu \mathrm{g} /$ cakram $(11,95 \pm 0,1 \mathrm{~cm})$. Penelitian ini juga menunjukkan bahwa senyawa antibakteri dari kapang $T$. asperellum MT02 lebih banyak dihasilkan sebagai metabolit ekstraselular yang disekresikan pada media kultur MEB. Hal ini didukung oleh Ismaiel dan Ali (2017) yang menyatakan bahwa senyawa antibakteri 6pentyl-a-pyrone dihasilkan oleh kapang Trichoderma sebagai metabolit ekstraselular yang dapat diekstrak menggunakan pelarut etil asetat. Senyawa antimikroba lain yang dihasilakn oleh genus Trichoderma dan diekstrak dengan etil asetat adalah 6methylthiochroman-4-one, 6-chlorothiochrom an-4-one, dan trichodermides A-E (Jiao et al. 2018; Pinedo-Rivilla et al. 2018;). Hasil penelitian ini dapat dilihat bahwa kapang $T$. asperellum MT02 berpotensi dijadikan sumber antibiotik baru untuk menyembuhkan infeksi bakteri patogen ESBL E. coli.

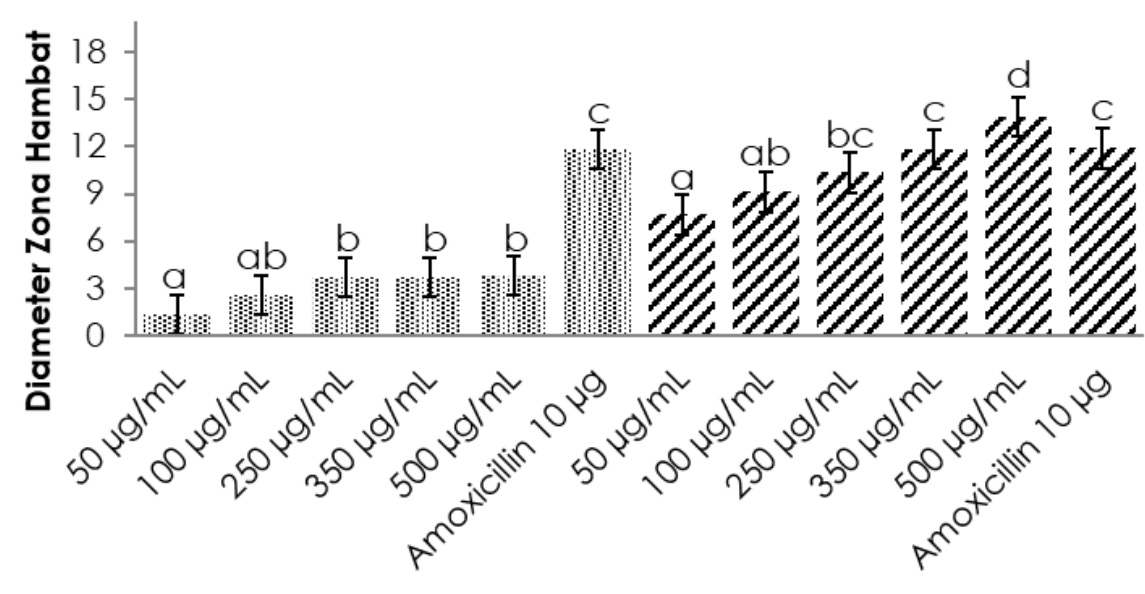

Konsentrasi

Gambar 2. Aktivitas antibakteri ekstrak kasar kapang T. asperellum MT02 (Keterangan = Miselia; $\boldsymbol{Z}=$ Media)

Tabel 2. Hasil analisis fitokimia ekstrak kasar kapang T. asperellum MTO2

\begin{tabular}{llcc}
\hline \multicolumn{1}{c}{ Golongan senyawa } & \multicolumn{1}{c}{ Parameter } & \multicolumn{2}{c}{ Hasil } \\
\cline { 2 - 4 } & \multicolumn{1}{c}{ Miselia } & Kaldu \\
\hline Alkaloid & & \\
- Metode Dragendorff & Endapan berwarna oranye hingga merah & - & + \\
- Metode Mayer & Endapan berwarna putih kekuningan & - & + \\
- Metode Wagner & Endapan berwarna cokelat & - & + \\
Fenol hidrokuinon & Perubahan warna menjadi hijau & + & + \\
Flavonoid & Perubahan warna menjadi jingga hingga merah & + & + \\
Saponin & Terbentuknya busa stabil selama 30 menit & - & + \\
Steroid/terpenoid & Perubahan warna dari merah menjadi biru dan & & - \\
& kehijauan & & - \\
\hline
\end{tabular}

Keterangan: $\quad+$ : Menunjukkan hasil yang sesuai dengan parameter

-: Menunjukkan hasil yang tidak sesuai dengan parameter 
Hasil karakterisasi golongan senyawa aktif menggunakan metode fitokimia pada Tabel 2 menunjukkan bahwa hanya terdapat dua golongan senyawa bioaktif pada miselium kapang $T$. asperellum MTO2 menggunakan pelarut metanol yakni fenol hidrokuinon dan flavonoid. Sedangkan ekstrak kasar dari media kaldu yang diekstrak menggunakan etil asetat mengandung alkaloid, fenol hidrokuinon, flavonoid dan saponin. Beberapa golongan senyawa yang dilaporkan dapat diekstrak oleh pelarut metanol adalah gula, asam amino, senyawa glycoside, senyawa fenolik, flavonoid, antosianin, terpenoid, saponin, tanin, xantoxilin, totarol, quacinoid, lacton, flavone, phenone, dan polifenol (Yu-Lin et al., 2009; Dehkharghanian et al., 2010; Widyawati et al. 2014). Grub senyawa bioaktif yang sebelumnya dilaporkan dapat diekstrak oleh etil asetat adalah alkaloid, aglicon, dan senyawa glikosida, sterol, terpenoid, dan flavonoid (Dehkharghanian et al., 2010; Liv et al., 2011; Widyawati et al. 2014). Penelitian ini juga memberikan informasi tambahan bahwa pelarut etil asetat juga mampu menarik senyawa fenol dan saponin dari dalam media kultur kapang.

Senyawa turunan dari golongan alkaloid, fenol dan flavonoid telah banyak dilaporkan sebagai antibakteri yang sangat potensial (Cushnie et al. 2015; Xie et al. 2015; Paz et al. 2018; Wang et al. 2019). Selain senyawa dari golongan alkaloid, fenol dan flavonoid, senyawa dari turunan nonribosomal peptide (NRP) dan poliketida (PK) juga banyak dilaporkan sebagai agen antibakteri yang sangat kuat. Kemampuan kapang ini untuk menghasilkan NRP dan PK dapat dilakukan melalui pendeteksian gen non-ribosomal peptide synthase (NRPS) serta gen polyketide synthase yang menyandikan enzim penghasil senyawa NRP dan PK. Hasil penelitian sebelumnya telah mengkonfirmasi bahwa T. asperellum MT02 memiliki gen penyandi NRPS serta mampu menghambat pertumbuhan bakteri patogen udang yakni Vibrio harveyii dan $V$. alginolyticus (Sibero et al. 20182), sehingga diduga bahwa kapang ini mampu menghasilkan senyawa antibiotik dari turunan NRP khususnya peptaibols. Hal ini diduga sangat berpengaruh atas kemampuan antibakteri ekstrak kapang ini melawan ESBL E. coli. Beberapa penelitian menyebutkan bahwa senyawa dari golongan alkaloid, fenol, flavonoid, peptaibols dan saponin memiliki potensi lain seperti antifungal, antivirus, antioksidan hingga antikanker (Peralta et al., 2018; Zhang et al., 2018; Wang et al., 2019), sehingga kapang T. asperellum MT02 juga diduga menjadi sumber obat masa depan penanganan penyakit menular hingga terapi kanker.

\section{KESIMPULAN}

Ekstrak kasar dari media kaldu kapang Trichoderma asperellum MT02 menunjukkan aktivitas antibakteri melawan ESBL E. coli yang lebih baik dibandingkan ektrak dari miseliumnya. Berdasarkan hasil analisis fitokimia diketahui bahwa ekstrak kasar miselium mengandung senyawa dari grub fenol hidrokuinon dan flavonoid, sedangkan ekstrak kasar dari media kaldu mengandung alkaloid, fenol hidrokuinon, flavonoid dan saponin.

\section{UCAPAN TERIMA KASIH}

Penulis mengucapkan terima kasih kepada Kementerian Riset, Teknologi dan Pendidikan Tinggi (Kemenristekdikti) yang telah membiayai penelitian ini melalui skema hibah riset Program Pendidikan Magister Menuju Doktor untuk Sarjana Unggul (PMDSU) dengan nomer kontrak 2993-12/UN7.5.1/PG/ 2016.

\section{DAFTAR PUSTAKA}

[CDC] Center for Disease Control and Prevention. 2018. Biggest Threats and Data. (Dapat diakses di: https://www.cdc.gov/drugresistance/big gest_threats.html\#ext). [Diakses pada 29 Oktober 2018]

[CLSI] Clinical Laboratory Standard Institute. 2016. Performance Standards for Antimicrobial Susceptibility Testing. 26th Ed. CLSI Supplement MIO0S.

Abdjul, D.B., Yamazaki, H., Kanno, S., Wewengkang, D.S., Rotinsulu, H., Sumilat, D.A., Ukai, K., Kapojos M.M. \& Namikoshi, M. 2017. Furanoterpenes, new types of protein tyrosine phosphatase 1B inhibitors, from two Indonesian marine 
sponges, Ircinia and Spongia spp. Bioorganic and Med. Chem. Lett. 27(5):1159-1161. DOI: 10.1016/j.bmcl.2017. 01.071

Bhai, R.S. \& Anandaraj, M. 2014. Enhancing shelf life of Trichoderma harzianum by conidial storage in sterile deionized water. J. Species Aromatic Crops. 23(2):243-249.

Cushnie, T.P.T., Cushnie, B. \& Lamb, A.J. 2015. Alkaloids: an overview of their antibacterial, antibiotic-enhancing and antivirulence activities. International Journal of Antimicrobial Agents 44(5): 377-386.

DOI: https://doi.org/10.1016/j.jjantimicag.2014. 06.001

Dehkharghanian, M., Adenier, H. \& Vijayalakshmi, M.A. 2010. Analytical methods study of flavonoids in aqueous spinach extract using positive electrospray ionization tandem quadrupole mass spectrometry. Food Chem. 121: 863-870. DOI: 10.1016/j.foodchem.2010.01. 007

Ebada, S. S., de Voogd, N.J., Kalschever, R., Müllerd, W.E.G., Chaidir \& Proksch, P. 2017. Cytotoxic drimane meroterpenoids from the Indonesian marine sponge Dactylospongia elegans. Phytochemistry Letters 22: 154-158. DOI: http://dx.doi.org/10.1016/j.phytol.2017.09. 026

Fredimoses, M., Zhou, X., Ai, W., Tian, X., Yang, B., Lin, X., Liu, J., Liu, Y. 2018. Emerixanthone $E$, a new xanthone derivative from deep sea fungus Emericella sp SCSIO 05240. Natural Product Research 17: 1-7. DOI: 10.1080/14786419.2018.1487966.

Guillerme, J.B., Couteau, C. \& Coiffard, L. 2017. Application for marine resources in cosmetics. Cosmetics 4(35). DOI: 10.3390/cosmetics4030035

Hidayat, T. \& Nurnajah, N. 2016. Chemical compositions, extraction and phytochemical Cyperus sp. plant. Frontiers in Biomedical Sciences 1 (1):7-12.

Ibrahim, S.R. \& Mohamed, G.A. 2017. Ingenine $E$, a new cytotoxic $\beta$-carboline alkaloid from the Indonesian sponge Acanthostrongylophora ingens. J Asian Nat. Prod. Res. DOI: 10.1080/10286020. 2016.1213723 labal, S., Ashfaq, M., Malik, A.H., Ul-Hag I, Khan, K.S. \& Mathews, P. 2017. Isolation, preservation and revival of Trichoderma viride in culture media. J. Entomology Zool. Stud. 5(3): 1640-1646.

Ismaiel, A.A. \& Ali, D.M.I. 2017. Antimicrobial properties of 6-pentyl-a-pyrone produced by endophytic strains of Trichoderma koningii and its effect on aflatoxin $\mathrm{Bl}$ production. Biologia 72(12):1403-1415. DOI: 10.1515/biolog2017-0173

Jiao, W.H., Khalil, Z., Dewapriya, P., Salim, A. A., Lin, H.W. \& Capon, R.J. 2018. Trichodermides A-E: new peptaibols isolated from the Australian termite nestderived fungus Trichoderma virens CMBTN16. J. Nat. Prod. 81(4): 976-984. DOI: 10.1021/acs.jnatprod. $7 b 01072$

Kitagawa, K., Shigemura, K., Yamamichi, F., Alimsardjono, L., Rahardjo, D., Kuntaman, K., Shirakawa, T. \& Fujisawa, M. 2018. International comparison of causative bacteria and antimicrobial susceptibilities of urinary tract infections between Kobe, Japan and Surabaya, Indonesia. Japan J. Infectious Disease 71: 8-13. DOI: 10.7883/yoken.JJID.2017.233

Liu, J., Wang, C., Wang, Z., Zhang, C., Lu, S., \& Liu, J. 2011. The antioxidant and freeradical scavenging activities of extract and fractions from corn silk (Zea mays L.) and related flavone glycosides. Food Chemistry 126: 261-269. DOI: 10.1016/j.foodchem.2010.11.014

Liv, Y., Ding, L., Fang, F. \& He, S. 2018. Penicillilactone A, a novel antibacterial 7membered lactone derivative from the sponge-associated fungus Penicillium sp. LS54. Nat.l Prod. Res. DOI: 10.1080/14786419.2018.1452012

Maarisit, W., Abdjul, D.B., Yamazaki, H., Kato, H., Rotinsulu, H., Wewengkang, D.S., Sumilat, D.A., Kapojos, M.M., Ukai, K. \& Namikoshi, M. 2017. Anti-mycobacterial alkaloids, cyclic 3-alkyl pyridinium dimers, from the Indonesian marine sponge Haliclona sp. Bioorg. Med. Chem. Lett. 27(15): 3503-3506. DOI: 10.1016/j.bmcl.20 17.05 .067

Natalia, D., Jo, C.M., Nusatia, A.C.M., \& Mayasari, M. 2018. Prevalence and risk factors of extended-spectrum betalactamases-producing Escherichia coli 
among adult inpatients in a secondary hospital. Adv. Sci. Lett. 24: 6817-6820. DOI: 10.1166 /asl.2018.12854

Paz, J.E.W., Contreras, C.R., Munguia, A.R., Aguilar, C.N. \& Inungaray, M.L.C. 2018. Phenolic content and antibacterial activity of extracts of Hamelia patens obtained by different extraction methods. Brazilian J. Microbiol. 49:656661. DOI: 10.1016/j.bjm.2017.03.018

Peralta, M.A., Ortega, M.G., Cabrera, J.L., \& Paraje, M.G. 2018. The antioxidant activity of a prenyl flavonoid alters its antifungal toxicity on Candida albicans biofilms. Food Chem. Tox. 114:285-291. DOI: 10.1016/j.fct.2018.02. 042

Pinedo-Rivilla, C., Collado, I.G. \& Aleu, J. 2018. Metabolism of antifungal Thiochroman-4ones by Trichoderma viride and Botrytis cinerea. J. Nat. Prod. 81 (4):1036-1040. DOI: 10.1021/acs.jnatprod.7 b00298

Sadek, P.C. 2002. The HPLC Solvent Guided, $2^{\text {nd }}$ Edition. New York (US): WileyInterscience.

Sibero, M.T., Radjasa, O.K., Sabdono, A., Trianto, A., Triningsih, D.W. \& Hutagaol, I.D. 2018'. Antibacterial activity of Indonesian sponge associated fungi against clinical pathogenic multidrug resistant bacteria. J. App. Pharmaceut. SCi. 8(2):88-94. DOI: 10.7324/JAPS.2018.82 14

Sibero², M. T., Herdikiawan, D., Radjasa, O. K., Sabdono, A., Trianto, A. \& Triningsih, D. W. 20182. Antibacterial activity of sponge associated fungi against vibriosis agents in shrimp and its toxicity to Litopenaeus vannamei. AACL Bioflux 11 (1): 10-18.

Sibero, M.T., Sabdaningsih, A., Cristianawati, O., Nuryadi, H., Radjasa, O. K., Sabdono \& Trianto, A. 2017. Isolation, identification and screening antibacterial activity from marine sponge-associated fungi against multi-drug resistant (MDR) Escherichia coli. IOP Conference Series: Earth and Environmental Science 55. DOI: 10.1088/1755-1315/55/1/012028

Stocco, M., Monaco, C. \& Cordo, C. 2010. A comparison of preservation methods for Trichoderma harzianum cultures. Revista Iberoamericana de Micologia 27(4): 213215. DOI: 10.1016/j.riam.20 10.06.001
Sudarwanto, M.B., Lukman, D.W., Purnawarman, T., Latif, H., Pisestyani, H. \& Sukmawinata, E. 2017. Multidrug resistance extended spectrum blactamase and AmpC producing Escherichia coli isolated from the environment of Bogor Slaughterhouse, Indonesia. Asian Pacific J. Trop. Biomed. 7(8):708-711. DOI: 10.1016/j.apjtb.2017. 07.012

Suleria, H.A.R., Osborne, S., Masci, P. \& Gobe, G. 2015. Marine-based nutraceuticals: an innovative trend in the food and supplement industries. Mar. Drugs 13(10):6336-6351. DOI: 10.3390\%2Fmd 131 06336

Wang, X. D., Su, G. Y., Zhao, C., Qu, F.Z., Wang, P. \& Zhao, Y.Q. 2019. Anticancer activity and potential mechanisms of $1 C$, a ginseng saponin derivative, on prostate cancer cells. J. of Ginseng Res. 42(2): 133143. DOI: 10.1016/j.jgr.2016.12.014

Wasito, E.B., Shigemura, K., Osawa, K., Fardah, A. Kanaida, A., Raharjo, D., Kuntaman, K., Hadi, U., Harijono, S., Sudarmo, S.M., Nakamura, T., Shibayama, K., Fujisawa, M. \& Shirakawa, T. 2017. Japan J. Infectious Disease. 70:378-382. DOI: 10.7883/yoke n.JJID.2016.234

Widyawati. P.S., Budianta, T.D.W., Kusuma, F. A. \& Wijaya, E.L. 2014. Difference of solvent polarity to phytochemical content and antioxidant activity of Pluchea indicia Less leaves extracts. Int. J. Pharmacog. Phytochem. Res. 6(4):850855.

Xie, Y., Yang, W., Tang, F., Chen, X., Ren, L. 2015. Antimicrobial activities of flavonoids: structure-activity relationship and mechanisms. Current Medicinal Chemistry 22: 132-149. DOI: 10.2174/0929867321666140916113443

Yu-Lin, H., Kuo, Y.H., Lin, Y.L. \& Chiang, W. 2009. Antioxidative effect and active component from leaves of lotus (Nelumbo nucifera). J. Agricul. Food Chem. 57:6623-6629. DOI: 10.1021/jf9 00950z

Zhang, X., Li, D., Xue, X., Zhang, Y., Zhang, J., Huang, C., Guo, Z. \& Tadesse, N. 2018. First total synthesis of a novel amide alkaloid derived from Aconitum 
taipeicum and its anticancer activity. Nat. Prod. Res. 32(2): 128-132. DOI: 10.1080/14 786419.2017.1340283

Zubair, M. S., Lallo, S., Putra, M. Y., Hadi, T. A. \& Jantan, I. 2018. Antibacterial and cytotoxic activities of sponges collected off the coast of Togean Islands, Indonesia. Pharmacognosy J. 10(5): 988992. DOI: 10.5530/pj.2018.5. 168 